\title{
Sobre la responsabilidad civil de los operadores eléctricos en materia de seguridad de las instalaciones, en el marco del ejercicio de una servidumbre eléctrica
}

\section{On the civil liability of electrical operators in the field of safety of the facilities, in the framework of the exercise of an electrical easement}

El presente artículo tiene por objeto abordar el problema del régimen jurídico al que se encuentra sujeta la responsabilidad civil de los operadores eléctricos en materia de seguridad de las instalaciones, en particular, en lo que dice relación con los deberes establecidos en el artículo 139 de la Ley General de Servicios Eléctricos y demás disposiciones reglamentarias que lo complementan, y cómo estas normas se vinculan con los deberes impuestos en los artículos 56 y 57 de la misma ley, al dueño de un predio gravado con servidumbre eléctrica.

Palabras clave: responsabilidad civil, operadores eléctricos, seguridad, servidumbre eléctrica.
The purpose of this article is to address the problem of the legal regime to which the civil liability of electrical operators is subject in terms of the safety of electrical systems, specially in relation to the duties established in article 139 of the General Law of Electrical Services and other regulatory provisions that complement it, and how these rules are related to the duties imposed in articles 56 and 57 of the same law, to the owner of a property taxed with electrical easement.

Keywords: civil liability, electrical operators, safety, electrical easement.

* Licenciado en Derecho, Abogado, Pontificia Universidad Católica de Chile. Doctor en Derecho, Universidad de Heidelberg, Alemania. Profesor de Derecho Civil y Derecho Romano en la Pontificia Universidad Católica de Chile. Dirección postal: Av. Libertador Bernardo O’Higgins 340, Santiago, Chile. Correo electrónico: aawegman@uc.cl.

Artículo recibido el 2 de junio de 2020 y aceptado el 3 de diciembre de 2020. 


\section{Introducción}

Al margen de la interesante discusión doctrinaria suscitada en nuestro país en los últimos años en torno el valor del derecho civil y, en particular, del código del ramo, como constitutivo de un derecho común incluso en el ámbito administrativo, la que abarca desde el reconocimiento de tal calidad ${ }^{1}$ hasta la calificación de la misma como un residuo histórico ${ }^{2}$, pasando por la reciente tesis, según la cual el verdadero derecho común para Chile sería la dogmática jurídica y no un cuerpo normativo concreto ${ }^{3}$, lo cierto es que en el contexto del así llamado derecho administrativo económico existen sectores más o menos amplios en los cuales, a falta de normativa especial, la aplicación principal o subsidiaria del derecho civil resulta indispensable. Un ejemplo de ello es el objeto del presente estudio, a saber, el problema de la determinación del régimen jurídico de la responsabilidad civil de los operadores eléctricos en materia de seguridad de las instalaciones, en el marco del ejercicio de una servidumbre eléctrica, particularmente en lo que concierne a sus relaciones con el dueño del predio sirviente.

\section{El deber de mantención de la seguridad en las instalaciones eléctricas}

1. La seguridad como idea directriz del marco regulatorio de los servicios eléctricos

Como es sabido, la normativa chilena sobre servicios eléctricos se encuentra inspirada en ciertas ideas directrices, calificadas en doctrina como principios del derecho eléctrico ${ }^{4}$, que les otorgan algunos caracteres esenciales, a saber: calidad, continuidad, obligatoriedad, regularidad, confiabilidad y seguridad.

En lo que respecta a la seguridad, esta se encuentra estrechamente vinculada con la noción de confiabilidad. En efecto, conforme a lo dispuesto en el art. 225 r) de la Ley General de Servicios Eléctricos ${ }^{5}$ ("LGSE"), se entiende por confiabilidad aquella "cualidad de un sistema eléctrico determinada conjuntamente por la suficiencia, la seguridad y la calidad de servicio". Por consiguiente, la confiabilidad incluye la suficiencia, esto es, según la letra s) del mismo artículo, el "atributo de un sistema eléctrico cuyas instalaciones son adecuadas para abastecer su demanda"; la seguridad, vale decir, de acuerdo a la letra t) de este artículo, la "capacidad de respuesta de un sistema eléctrico, o parte de él, para soportar contingencias y minimizar la pérdida de con-

\footnotetext{
1 Cfr. Bermúdez 2012, 65 y ss.

2 Vergara 2010, 74.

3 En este sentido recientemente MEJIAS 2018, 621 y ss.

4 Cfr. Vergara 2018a, 63 y ss.; Vergara 2018b, 144 y ss.

5 Decreto con Fuerza de Ley $N^{\circ} 4$ del Ministerio de Economía, Fomento y Reconstrucción (hoy Ministerio de Economía, Fomento y Turismo), de 2006.
} 
sumos, a través de respaldos y de servicios complementarios"; como también la calidad de servicio, en los términos de la letra $u)^{6}$.

Así las cosas, aunque el art. 225 r) LGSE incluye la seguridad dentro del concepto más amplio de confiabilidad, lo cierto es que aquélla merece ser tenida como una idea directriz autónoma del marco regulatorio de los servicios eléctricos, en la medida que lo irradia axiológicamente. De hecho, la preservación de la seguridad del servicio forma parte de los principios de la coordinación de la operación del sistema eléctrico nacional, conforme al numeral primero del art. 72-1 LGSE.

Ahora bien, de un atento análisis de la normativa sectorial resulta que la idea de seguridad en ella contenida no es unívoca, sino que se desdobla en dos nociones distintas, aunque mutuamente complementarias: si por una parte el art. 225 t) LGSE recién mencionado se refiere directamente a exigencias de seguridad del servicio dirigidas a todos los segmentos del sistema eléctrico, esto es, a la confiabilidad de los subsistemas de generación, transporte y distribución, donde el mayor riesgo a conjurar es la interrupción del suministro eléctrico ${ }^{7}$, otras normas de la LGSE, en particular, en lo que concierne al objeto del presente trabajo, su art. 139 y demás disposiciones reglamentarias que lo complementan, encuentran su ratio más bien en un intento de minimizar el riesgo de accidentes y consiguientes daños a las personas o a las cosas. Todo lo cual, por cierto, tiene importantes consecuencias en materia de responsabilidad patrimonial de los operadores por daños sufridos por terceras personas o cosas ajenas por eventuales defectos en la mantención de las instalaciones eléctricas.

2. Deberes de los operadores eléctricos en materia de seguridad de las instalaciones. Interpretación administrativa y judicial

Analicemos las normas atingentes a la cuestión planteada. El precepto fundamental en la materia es el art. 139 LGSE, que dispone lo siguiente:

[1] Es deber de todo concesionario de servicio público de cualquier naturaleza mantener las instalaciones en buen estado y en condiciones de evitar peligro para las personas o cosas, de acuerdo a las disposiciones reglamentarias correspondientes. [2] En iguales condiciones de seguridad se deberán encontrar las instalaciones de energía eléctrica de uso privado. [3] Las infracciones a lo dispuesto en los incisos anteriores serán sancionadas con las multas que establezca previamente el reglamento.

\footnotetext{
6 El artículo 225 u) LGSE define la calidad como un "atributo de un sistema eléctrico determinado conjuntamente por la calidad del producto, la calidad del suministro y la calidad de servicio comercial, entregado a sus distintos usuarios o clientes". Por ende, se trata de un concepto que engloba distintos aspectos de la prestación del servicio de parte de los operadores eléctricos a los usuarios o clientes, que puede desglosarse en "calidad del producto" según el art. 225 v) LGSE; "calidad del suministro" de la letra w) del mismo artículo; y "calidad de servicio comercial", definida en la letra $x$ ) de este artículo.

7 Cfr. Sepúlveda 2010, 80.
} 
En cuanto a las disposiciones reglamentarias aludidas en la norma recién citada, la primera que debe ser tomada en consideración es el art. 205 del Reglamento de la Ley General de Servicios Eléctricos ${ }^{8}$ ("RLGSE"), el cual, en términos igualmente genéricos, establece que:

es deber de todo operador de instalaciones eléctricas en servicio, sean de generación, transporte o distribución, y de todo aquel que utilice instalaciones interiores, mantenerlas en buen estado de conservación y en condiciones de evitar peligro para las personas o daño en las cosas.

Evidentemente, este deber consiste en un facere, sin que se explicite qué significa en concreto mantener las instalaciones en tales condiciones y, por tanto, cuál es el contenido específico de tal deber, circunstancia que también trae consigo cierta ambigüedad en cuanto al estándar de diligencia a emplear, la cual se plasma, como veremos, en la interpretación administrativa y judicial de los preceptos citados.

Otras disposiciones reglamentarias ofrecen más detalles respecto a cómo ha de cumplirse este deber de seguridad, estableciendo que el operador debe cortar o podar especies arbóreas, e incluso a derribarlas, cuando puedan afectar la seguridad de las líneas. Así, el art. 206 RLGSE señala en su inciso primero que:

las especificaciones técnicas de todo proyecto eléctrico, así como su ejecución, operación y mantenimiento, deberán ajustarse a las normas técnicas y reglamentos vigentes. En especial, deberán preservar el normal funcionamiento de las instalaciones de otros concesionarios de servicios públicos, la seguridad y comodidad de la circulación en las calles, caminos y demás vías públicas, y también la seguridad de las personas, las cosas y el medio ambiente.

En relación con ello, el art. 214 del mismo reglamento dispone en su inciso primero que:

los operadores de instalaciones eléctricas deberán contar con personal de emergencia para la reparación de fallas que afecten la continuidad - la calidad del suministro, que produzcan riesgo a la seguridad de las personas o daño en las cosas, que obstruyan las vías públicas o que dificulten el tránsito normal de las personas y vehículos. Por su parte, el art. 218 establece que "los operadores de instalaciones eléctricas deberán incluir en sus programas de mantenimiento la poda o corte de los árboles que puedan afectar la seguridad de sus instalaciones, utilizando técnicas adecuadas para preservar las especies arbóreas (...).

Más recientemente, el Reglamento de Seguridad de las Instalaciones Eléctricas destinadas a la Producción, Transporte, Prestación de Servicios Complementarios, Sistemas de Almacenamiento y Distribución de Energía

8 Decreto $N^{\circ} 327$ del Ministerio de Minería, de 1997. 
Eléctrica9 ("RSIE") contiene en su Título II normas sobre "Responsabilidades" de los operadores de instalaciones eléctricas, disponiendo en su art. $4^{\circ}$ que "los propietarios u operadores de todo tipo de instalaciones eléctricas, serán responsables de dar cumplimiento a las normas de seguridad establecidas en la ley, en la reglamentación vigente y en las normas técnicas sobre la materia". Asimismo, señala en su art. $5^{\circ}$ que:

toda instalación eléctrica deberá ejecutarse de acuerdo a un proyecto técnicamente concebido, el cual deberá asegurar que la instalación no presente riesgos para las personas o las cosas, cumpliendo además con las condiciones de eficiencia, y mantenimiento, establecidas en la normativa vigente.

Finalmente, cabe hacer presente que el art. $2^{\circ}$ de la Ley $N^{\circ} 18.410$, de 1985, que crea la Superintendencia de Electricidad y Combustibles ("LSEC"), faculta a dicho organismo para "fiscalizar y supervigilar el cumplimiento de las obligaciones legales y reglamentarias y normas técnicas sobre generación, producción, almacenamiento, transporte y distribución de combustibles líquidos, gas y electricidad para verificar que la calidad de los servicios que se preste a los usuarios sea la señalada en dichas disposiciones y normas técnicas, y que las antes citadas operaciones y el uso de los recursos energéticos no constituyan peligro para las personas o cosas". En el ejercicio de tales funciones, la SEC ha dictado normativa especial, que vincula a los operadores eléctricos en virtud del art. 223 LGSE $^{10}$, en concreto, los Oficios Circulares $\mathrm{N}^{\circ} 2.824$ de 2013, No2.999 de 2015, y, especialmente, $\mathrm{N}^{\circ} 26.035$ de 2017, que imparte Instrucciones sobre Mantenimiento de Instalaciones, Corte y Poda de Árboles en las Proximidades de Líneas Eléctricas ("Oficio Circular").

Pues bien, el Oficio Circular, vinculando las dos nociones de seguridad antes señaladas, esto es, por una parte, la seguridad del servicio, identificada con la confiabilidad del suministro eléctrico, y, por la otra, la seguridad de las personas y las cosas, señala en su numeral 2.2 lo siguiente:

Como condición inherente al deber que tienen las empresas de dar un suministro continuo, de calidad y seguro, se distingue el deber de mantener las instalaciones. Este deber se consagra en el artículo 139 de la ley (...). El deber de mantener implica ejecutar las acciones orientadas a conservar una continuidad y seguridad de suministro, monitoreando y gestionando aquellas situaciones que impidan brindar dicha continuidad o bien identificando los

\footnotetext{
9 Decreto N 109 del Ministerio de Energía, de 2017.

10 El art. 223 LGSE establece en su inciso segundo lo siguiente: "Es responsabilidad de los propietarios de todo tipo de instalaciones eléctricas el cumplir con las normas técnicas y reglamentos que se establezcan en virtud de la presente ley; el no cumplimiento de estas normas o reglamentos podrá ser sancionada por la Superintendencia con multas y/o desconexión de las instalaciones correspondientes, en conformidad a lo que establezcan los reglamentos respectivos". Por otra parte, conforme al art. 72-6 LGSE, corresponde al Coordinador Eléctrico Nacional exigir a los operadores el cumplimiento de la normativa técnica y los requerimientos técnicos que instruya. Sobre las facultades de este organismo y, en especial, sobre su régimen de responsabilidad, véase PARADA 2019, 85 y ss.
} 
riesgos que la amenacen para luego ejecutar acciones destinadas a mitigarlos o resolverlos (...).

En cuanto al deber de revisión de franja y roce de líneas con árboles situados dentro de aquélla o en sus inmediaciones, su sentido y alcance es fijado con minucioso detalle en el numeral 2.2(ii) Oficio Circular, que en lo sustancial dispone que el operador debe revisar y despejar las especies arbóreas existentes en la franja de seguridad de sus líneas conforme con sus respectivos planes de roce o planes de acción, teniendo presente además, las obligaciones contenidas en las respectivas resoluciones de calificación ambiental; despeje, tala o poda que está asociado especialmente a la eliminación de un peligro que pueda afectar a esas instalaciones para los efectos de otorgar un suministro eléctrico continuo. Adicionalmente, el operador debe revisar y gestionar la remoción de riesgos de árboles que, a su juicio, representen un riesgo inminente para la línea y la continuidad del servicio, no agotándose esta obligación en la franja de seguridad, sino que extendiéndose a los árboles vecinos o próximos que puedan constituir una amenaza o riesgo para las instalaciones. A partir de esto, la SEC deduce que el operador tiene el deber de vigilar permanentemente que, en el recorrido de la línea, no existan especies arbóreas cuya altura y condición evidente, constituyan una real amenaza, peligro o riesgo para la instalación y, en consecuencia, para la continuidad de suministro, todo ello acorde con los planes de roce de la empresa y los planes de acción propuestos a la misma SEC, siendo la gestión del riesgo de seguridad de la línea de responsabilidad del operador de la instalación perturbada.

Así, en la interpretación de la SEC, del art. 139 LGSE se desprenderían deberes específicos como, por ejemplo, el de revisar y gestionar la remoción de las especies arbóreas presentes en la franja de seguridad y en sus inmediaciones, conforme con los respectivos planes de roce, muy especialmente cuando haya un riesgo inminente para las instalaciones y la continuidad del servicio. Lo anterior, en el contexto de un deber de vigilancia permanentemente, de lo que podría concluirse que la gestión de esta clase de riesgos es de exclusiva responsabilidad del operador ${ }^{11}$.

Llegados a este punto, hay que destacar la circunstancia que tanto la normativa legal y reglamentaria como la interpretación administrativa y judicial, cuando discurren sobre la responsabilidad del dueño del predio sirviente, aluden únicamente a posibles perturbaciones al libre ejercicio de la servidumbre o peligros a la seguridad del servicio y, por ende, del suministro eléctrico continuo, sin referencia alguna a daños que eventualmente pudieran producirse en las personas o en las cosas. Si, por una parte, el art. 56 LGSE impone al propietario del suelo un deber de tolerancia, consistente en "permitir la entrada de inspectores y trabajadores debidamente identificados para efectuar trabajos de reparación, bajo la responsabilidad del concesiona-

\footnotetext{
11 Esto es particularmente relevante cuando no se trata simplemente de plantaciones o algunos árboles en la franja de servidumbre, sino que derechamente de bosques. Al respecto véase MACHUCA 2017, 135 y ss.
} 
rio a quien dichas líneas pertenecen", el art. 57 LGSE, por la otra, le impone un deber de abstención, en cuanto:

no podrá hacer plantaciones, construcciones ni obras de otra naturaleza que perturben el libre ejercicio de las servidumbres establecidas por esta ley (...). Si infringiere esta disposición o sus plantaciones o arboledas crecieren de modo que perturbaren dicho ejercicio, el titular de la servidumbre podrá subsanar la infracción a costa del dueño del suelo.

Como puede apreciarse, ninguno de los preceptos transcritos alude a una responsabilidad patrimonial directa del dueño del previo sirviente por los daños que eventualmente pudieran sufrir terceras personas o cosas a raíz de su infracción normativa.

Distinto es el caso de los operadores eléctricos, cuyos deberes de mantención de las líneas se vinculan explícitamente tanto a la seguridad del suministro eléctrico como a evitar peligro de daño a personas y cosas. A partir de lo anterior, es posible sostener que de las dos nociones de seguridad que informan la normativa eléctrica, mientras las infracciones a los arts. 56 y 57 LGSE que pudieran imputarse al dueño del predio sirviente, son tomadas en consideración únicamente como un riesgo a la continuidad del suministro energético, las infracciones en las que pueda incurrir un operador eléctrico también son consideradas (y sancionadas) en la medida que pueden dar lugar a perjuicios a terceras personas o a cosas ajenas.

Si se lee conjuntamente y se intenta una interpretación armónica del art. 139 LGSE, los arts. 205, 206 y 218 RLGSE, los arts. $4^{\circ}$ y $5^{\circ} \mathrm{RSIE}$ y el numeral 2.2 Oficio Circular, en una primera aproximación, estos preceptos parecieran endosar al operador de instalaciones eléctricas la obligación de evitar los daños producidos por la inobservancia por parte del dueño del predio superficial del deber de abstención contenido en el art. 57 LGSE o, incluso, una suerte de obligación de supervigilancia respecto del cumplimiento de este último. Tanto es así que la Corte Suprema, en un fallo relativamente reciente, ha resuelto que el deber que recae sobre los operadores eléctricos en materia de revisión de la franja y de roce de las líneas de árboles a la luz de lo dispuesto en la normativa legal y reglamentaria y, en especial, en el Oficio Circular, no requiere gestionar una autorización previa, sino que basta con lo dispuesto en la LGSE, como asimismo, que los operadores tienen el deber de efectuar directamente las obras de despeje, remoción o corte de los árboles que representen un peligro para la seguridad de las líneas, lo que podría dar a entender que, en última instancia, la responsabilidad es del operador y no del dueño del predio sirviente ${ }^{12}$.

\footnotetext{
12 Corte Suprema. Rol No 14853-2018, c. 12: "Que, en el referido Oficio Circular N²6.035, de 15 de diciembre de 2017, la Superintendencia ha instruido a las empresas en el sentido que la obligación de revisión de la franja y de roce de las líneas de árboles comprende también la obligación de despeje de la misma, que implica 'retirar toda la vegetación o también el material que con ocasión de incendios pueda afectar la seguridad de la línea', facultando a la empresa para que intervenga en la vecindad y retire toda la vegetación o material, sin necesidad de
} 
En una línea interpretativa similar, se ha establecido que, si bien la negativa del dueño del terreno superficial a que trabajadores de la concesionaria puedan efectuar obras de reparación constituye un acto ilegal y arbitrario por vulnerar los arts. 56 y 57 LGSE, los operadores de instalaciones eléctricas no solo están facultados para realizar trabajos de mantención de las líneas, sino que se encontrarían "principalmente obligados a ello", lo que pareciera deja entrever que, ante todo, sería un deber de estos últimos mantener las instalaciones en buen estado de conservación y en condiciones de evitar peligro para las personas o daño en las cosas, con independencia del comportamiento ilegal del dueño del predio sirviente ${ }^{13}$. Así, según la comprensión de la corte sobre la normativa sectorial de los servicios eléctricos, la infracción de los arts. 56 y 57 LGSE por parte del dueño del terreno superficial no representaría en sí misma un obstáculo serio para que el operador pueda cumplir su deber de revisión de la franja de servidumbre, que eventualmente la despeje e, incluso, que proceda a la remoción de los árboles que representen un riesgo inminente para la línea y la continuidad del servicio, aun contra la voluntad del propietario del predio sirviente, ya que bastaría la autorización de ingreso otorgada por las normas referidas.

Consecuencialmente, cabe sostener que tanto la interpretación judicial como administrativa del marco jurídico de los servicios eléctricos se inclinan por negar a los operadores la posibilidad de alegar eficazmente, por ejemplo, que un incendio se provocó por el contacto de las líneas de distribución con ramas de árboles que no deberían haber estado allí si el dueño del predio sirviente hubiese cumplido el deber de abstención impuesto en el art. 57 LGSE o, al menos, no entorpecido las obras de reparación conforme al art. 56 LGSE. Para nuestro máximo tribunal, los operadores eléctricos no solo están facultados, sino que se encuentran principalmente obligados a ejecutar "todas las labores que resulten necesarias" para la mantención de las instalaciones.

\footnotetext{
gestionar la autorización respectiva, conforme con lo preceptuado en el artículo 57 del D.F.L. $N^{\circ} 4 / 20.018$, Ley General de Servicios Eléctricos y con las disposiciones contenidas en la Norma de Seguridad N5 E.N. 71 para Instalaciones de Corrientes Fuertes. Asimismo, de lo expuesto se puede colegir que, para los efectos de realizar estos trabajos conservativos de la seguridad de la línea de media tensión, resulta suficiente la autorización de ingreso que se encuentra contenida en la propia Ley General de Servicios Eléctricos, que se deriva de lo preceptuado por sus artículos 51 y $56^{\prime \prime}$.

13 Corte de Apelaciones de Concepción. Rol N¹5276-2018, c. 5: "Que, entonces, de este panorama normativo básico se desprende razonablemente que las empresas concesionarias no solo están facultadas, sino que se encuentran principalmente obligadas, a ejecutar todas las labores que resulten necesarias para la mantención de las servidumbres eléctricas de que son titulares, y si bien la ley habla de 'reparación', lo cierto es que esta actividad debe entenderse incluyendo, como es lógico, la conservación de las instalaciones, única forma en que estas funcionen en situación de garantizar el servicio de utilidad pública que importa el transporte y suministro de electricidad".
} 
3. Deberes del propietario del predio sirviente. Interpretación administrativa y judicial

En lo que respecta al propietario sirviente, como ya se adelantó, el art. 57 LGSE consagra la prohibición de hacer plantaciones, construcciones u obras de otra naturaleza que perturben el libre ejercicio de las servidumbres establecidas por dicha ley, de modo que la infracción de esta disposición autoriza al operador a subsanarla a costa del dueño del suelo. Asimismo, en caso de que sea necesario efectuar trabajos de reparación o poda, el art. 56 LGSE le impone el deber de permitir la entrada de inspectores y trabajadores para efectuar tales trabajos, bajo la responsabilidad del operador, para lo cual tiene derecho al pago de una indemnización por el tránsito a que estos trabajos den lugar ${ }^{14}$. Así las cosas, la delimitación de deberes y responsabilidades entre una y otra parte exige un esfuerzo hermenéutico, en orden a armonizar los preceptos legales y reglamentarios citados.

No cabe duda de que la presencia de vegetación cerca de líneas de distribución de energía eléctrica constituye por sí misma un riesgo para la seguridad del servicio, debido al potencial contacto de ramas de árboles o arbustos con cables. De ahí que el Oficio Circular disponga en su numeral 2.2(ii) que, si bien la gestión del riesgo de seguridad de las líneas es responsabilidad del operador de la instalación perturbada, conforme con los planes de roce y planes de acción exigidos por la SEC, a la luz de lo establecido en el artículo $57^{\circ}$ de la LGSE:

es responsabilidad del propietario del inmueble colindante con instalaciones eléctricas no hacer construcciones o plantaciones, ni dejar crecer arboledas que, por sus condiciones, se transformen en un riesgo para el servicio público de distribución y/o transmisión, y en caso que, no obstante lo anterior, estas se detecten, contribuir a la expedita eliminación o mitigación del riesgo.

Asimismo, con respecto a construcciones ubicadas bajo las líneas eléctricas en contravención a la normativa, el numeral 2.2(i) Oficio Circular, luego de establecer que es deber de los operadores monitorear permanentemente sus líneas, a fin de adoptar medidas para evitar que se construya bajo ellas, dispone que:

(...) conforme lo dispone el artículo $57^{\circ}$ de la LGSE, también es obligación del dueño del predio sirviente, no realizar construcciones que puedan perturbar el libre ejercicio de la servidumbre de la empresa, por lo que, de constatarse tanto la construcción corno la perturbación, esto podría ser calificado y tratado administrativamente como una infracción

\footnotetext{
${ }_{14} \mathrm{El}$ art. $69 \mathrm{~N}^{\circ} 3$ LGSE establece en favor del dueño del predio sirviente el derecho a que se le pague "una indemnización por el tránsito que el concesionario tiene derecho a hacer para los efectos de la custodia, conservación y reparación de las líneas (...)". Sobre los regímenes de acceso y tránsito al predio sirviente véase últimamente Díaz 2018, 41 y ss.
} 
por parte del propietario del predio o bien, del poseedor que se repute como dueño.

Como puede apreciarse, la SEC alude explícitamente al carácter de infracción administrativa de la inobservancia por parte del dueño del predio sirviente del deber especial de abstención consagrado en el art. 57 LGSE, de lo que en principio podría resultar su responsabilidad patrimonial directa por los daños que ello pudiera ocasionar.

De esta guisa, la vulneración del deber especial de abstención contenido en el art. 57 LGSE respecto del dueño del suelo podría representar -ciertamente en la medida que se provoque un daño- una hipótesis de ilícito civil en la modalidad de culpa infraccional, es decir, una contravención de los deberes de cuidado establecidos por el legislador $u$ otra autoridad con potestad normativa (la ley, un reglamento, un oficio circular, etc. $)^{15}$, cuestión esta última en la que nos detendremos en el acápite siguiente. La Corte Suprema ha fallado en consecuencia ${ }^{16}$.

Abona lo dicho el Ordinario N 195 de la Dirección Regional de la Araucanía de la SEC, de 21 de junio de 2019 ("Ordinario 195"), en el cual, a propósito de la inobservancia del art. 57 LGSE por parte de una empresa forestal propietaria de un predio gravado con servidumbre eléctrica, se estableció que hay obligaciones y responsabilidades:

que asisten tanto a las empresas eléctricas como al dueño de los predios en que se ubican árboles cercanos a las redes eléctricas (...) contexto en el cual se instruyó verbalmente al administrador del predio la tala de los árboles, o la adopción de cualquier otra medida forestal que permitiera eliminar la condición de riesgo (...) lo que a la fecha no se ha cumplido (...) en este contexto, se debe tener presente que la normativa eléctrica (...) resulta aplicable tanto a los operadores de redes eléctricas como a los propietarios de plantaciones, por tanto, en este caso existe un claro incumplimiento por parte del propietario de los árboles respecto de la normativa eléctrica referida (...).

A mayor abundamiento, en lo que pareciera representar una jurisprudencia uniforme de nuestros tribunales superiores de justicia, se ha fallado que la negativa injustificada a permitir a trabajadores del operador eléctrico el ingreso al predio sirviente para realizar obras de mantención y reparación, amén de dar lugar a una infracción al mencionado art. 56 LGSE, constituye una acción ilegal y arbitraria que afecta el derecho de propiedad del operador sobre las instalaciones eléctricas y, se podría agregar, su derecho de propiedad sobre la servidumbre, en virtud de lo dispuesto en el art. $19 \mathrm{~N}^{\circ} 24$

15 Cfr. Barros 2020, T 1, 104.

16 Véase Corte Suprema Rol. N³4224-2017, c. $11^{\circ}$. 
de la Constitución Política de la República ("CPR"), precepto que reconoce la propiedad sobre toda clase de bienes corporales e incorporales ${ }^{17}$.

Por cierto, no hay que olvidar que lo expuesto precedentemente se presenta en el contexto de las limitaciones que impone al dueño del suelo la constitución de una servidumbre, inherente a la concesión eléctrica ${ }^{18}$. En la medida que el gravamen de la servidumbre consiste en el deber que tiene el dueño del predio sirviente de tolerar ciertos actos de uso por parte del dueño del predio dominante ${ }^{19}$, o de abstenerse de ejecutar ciertas facultades inherentes al dominio ${ }^{20}$, su constitución no puede significar -al menos en principio- imponer al propietario del suelo la ejecución de actos positivos (idea expresada en el viejo aforismo servitus in faciendo consistere nequit), no obstante lo dispuesto en el art. 823 del Código Civil ("CC") ${ }^{21}$. En este sentido, es muy importante destacar que la servidumbre eléctrica es un derecho real limitado sobre un predio en el cual se encuentran instalaciones eléctricas que no son del dueño del suelo y, por ende, una limitación al dominio, pero no una

\footnotetext{
17 Así, por ejemplo, Corte Suprema Rol N 14853-2018, c. 15: “(..) aparece con toda claridad que la negativa de la recurrida a franquear el ingreso de los trabajadores de la actora al predio en el que se instala, o por el que pasa el tendido eléctrico de cuya mantención es responsable la empresa recurrente, resulta ilegal, desde que contraviene el texto expreso de las disposiciones recién citadas. Asimismo, esta conducta puede ser reprochada de caprichosa y contraria a la razón o buen juicio, teniendo en vista que la normativa legal y reglamentaria se orienta al aseguramiento de las personas y cosas, y a la protección del medioambiente, del cual la propia recurrida resulta beneficiaria, de modo que debe ser también calificada de arbitraria", como asimismo, que "la conducta desplegada por la recurrida, indicada en el motivo precedente, importa una acción de autotutela, en virtud de la cual la recurrente se ha visto en la imposibilidad, de manera imprevista e inconsulta, de cumplir con su obligación legal de dar mantenimiento al tendido eléctrico, esto es, de realizar las labores de inspección y mantenimiento que la ley le impone en aras de asegurar la integridad del oleoducto y de evitar los riesgos de incendio forestal que involucra la existencia de vegetación y otros materiales combustibles en la franja se seguridad del tendido eléctrico". En términos casi idénticos la misma corte, en sentencias de la misma fecha y de roles correlativos Corte Suprema Rol $N^{\circ} 14854-2018$, c. $12^{\circ}$, Corte Suprema Rol No $14855-2018$, c. $14^{\circ}$, Corte Suprema Rol N ${ }^{\circ} 14856-$ 2018 , c. $15^{\circ}$, y Corte Suprema Rol N ${ }^{\circ} 14857-2018$, c. $15^{\circ}$ ), y en sentencia Corte Suprema Rol $N^{\circ} 115-2018$, c. $10^{\circ}$. Véase también Corte de Apelaciones de Concepción Rol N 7093-2013 c. $10^{\circ}$ y $11^{\circ}$ : "Que de acuerdo a lo que se ha expresado, la negativa de la recurrida de impedir el acceso a su predio del personal de la Cooperativa recurrente, para realizar las labores ya indicadas, resulta ilegal pues infringe las disposiciones antes consignadas, que son las que regulan la situación ocurrida en estos autos, vale decir, aquella de mantener la seguridad de redes de tendido eléctrico que atraviesan terrenos de terceros (...). Que el acto arbitrario e ilegal ya descrito afecta el legítimo ejercicio del derecho de propiedad de la recurrente sobre sus instalaciones eléctricas (...)". En términos similares la misma corte, en sentencias. Corte de Apelaciones de Concepción Rol N 6990-2017, Corte de Apelaciones de Concepción Rol $N^{\circ}$ 6948-2017 y Corte de Apelaciones de Concepción Rol N 867-2018.

18 Véase art. $2^{\circ} \mathrm{N}^{\circ} 4$ LGSE.

19 En la especie, el predio dominante consistiría en la instalación eléctrica, que si bien no constituye un inmueble por naturaleza, sí lo es por adherencia o destinación, según el caso.

20 Cfr. Alessandri et al. 2016, 181.

21 Cabe hacer presente que si bien el art. 823 CC se refiere en su inciso segundo a la posibilidad de que las servidumbres positivas impongan al dueño del predio sirviente la obligación de hacer algo, el ejemplo allí aludido, esto es, la hipótesis descrita en el art. 842 CC, no corresponde propiamente a una servidumbre.
} 
desmembración del mismo. Lo dicho significa que la constitución de una servidumbre eléctrica no trae consigo que el propietario del predio sirviente pierda las facultades inherentes a su derecho de dominio (ius utendi, ius fruendi e ius abutendi: facultades de uso, goce y disposición), sino simplemente la carga de ejercerlas dentro de los límites que le impone el gravamen ${ }^{22}$.

Con todo, si bien la servidumbre no impone en principio deberes positivos, sino solo negativos (tolerancia de actos ajenos o abstención de actos propios), ello ha de ser armonizado con la regla contenida en el art. 828 CC, en cuanto a que el titular de una servidumbre tiene derecho a todos aquellos medios que razonablemente sean necesarios para ejercerla ${ }^{23}$. De ahí que en situaciones concretas el dueño del predio sirviente sí podría, indirectamente, estar obligado a "hacer algo" a favor del titular de la servidumbre, en cuanto los medios necesarios para ejercerla supongan cierto grado de cooperación activa de parte del primero y no meramente pasiva. Un ejemplo de lo dicho sería, precisamente, la prohibición al propietario del predio sirviente de hacer plantaciones, construcciones u obras de otra naturaleza que perturben el libre ejercicio de la servidumbre (art. 57 LGSE), lo que indirectamente puede traer consigo la obligación de podar, talar o demoler lo ya plantado o construido y, por consiguiente, un "hacer". Lo anterior, en cuanto aplicación especial en materia de servicios eléctricos del principio general establecido en el art. 830 CC, según el cual el dueño del predio sirviente no puede alterar, disminuir, ni hacer más incómoda para el predio dominante la servidumbre con que está gravado el suyo, y sin perjuicio de que, en todo caso, las obras indispensables para ejercer la servidumbre son de cargo del que la goza (art. $829 \mathrm{CC}$ ).

De lo expuesto precedentemente resulta que existe cierta complementariedad o correlatividad, como ha sostenido la Corte Suprema, entre la observancia del dueño del predio sirviente de los deberes de tolerancia y abstención que le impone el gravamen legal, por una parte, y las obligaciones que la LGSE impone al operador eléctrico en materia de seguridad de las instalaciones, en el marco del ejercicio de una servidumbre eléctrica, por la otra ${ }^{24}$. En efecto, el cumplimiento por parte del propietario del suelo de los deberes establecidos en la ley en materia de servidumbres, y muy especialmente en los arts. 56 y 57 LGSE como especificación del deber general contenido en el art. 830 CC, representa una condición indispensable para el cumplimiento por parte del operador eléctrico de su obligación de manten-

\footnotetext{
22 Evans 2006, 109. Cfr. Peñallillo 2019, 1260 y ss.; Corral 2020, 515 y ss.

23 Art. 828 CC: "El que tiene derecho a una servidumbre, lo tiene igualmente a los medios necesarios para ejercerla. Así, el que tiene derecho de sacar agua de una fuente situada en la heredad vecina, tiene el derecho de tránsito para ir a ella, aunque no se haya establecido expresamente en el título". Cfr. Alessandri et al. 2016, 191.

24 Corte Suprema. Rol N 14853-2018, c. 10: "Que, para los efectos del cumplimiento de dichas obligaciones, la misma ley ha dispuesto, en su artículo 56, una correlativa que pesa sobre el dueño del predio sirviente de la servidumbre contemplada en el artículo 51 de la sobredicha ley, de permitir la entrada de inspectores y trabajadores para efectuar las labores de reparación".
} 
ción contenida en el art. 139 LGSE y demás disposiciones reglamentarias que lo complementan, todo lo cual exige un esfuerzo hermenéutico en orden a delimitar los respectivos ámbitos de responsabilidad civil de una y otra parte, según se trata a continuación.

\section{Régimen de responsabilidad civil aplicable a los operadores eléctri- cos en el contexto descrito}

Como ya se expuso, tanto la normativa legal y reglamentaria como la jurisprudencia administrativa y judicial analizadas, cuando discurren sobre las infracciones del dueño del predio sirviente a los arts. 56 y 57 LGSE, aluden únicamente a posibles perturbaciones al libre ejercicio de la servidumbre o peligros para la seguridad del suministro eléctrico continuo, sin referencia alguna a daños patrimoniales o extrapatrimoniales que eventualmente pudieran producirse. En cambio, cuando se ocasiona un daño a las personas o las cosas, se tiende a atribuir la responsabilidad al operador eléctrico, incluso cuando ello se debe a un entorpecimiento por parte del dueño del suelo a las labores de mantención de las instalaciones del operador.

Pues bien, a falta de normativa especial en materia de responsabilidad civil de los operadores eléctricos, esta ha de quedar sometida al régimen jurídico común, esto es, al contenido en el Título XXXV "De los delitos y cuasidelitos" del Libro Cuarto del Código Civil (arts. 2314 ss. CC), el cual comienza estableciendo el principio básico aplicable en la materia, al disponer que "el que ha cometido un delito o cuasidelito que ha inferido daño a otro, es obligado a la indemnización; sin perjuicio de la pena que le impongan las leyes por el delito o cuasidelito" (art. 2314 CC.). Expresa en lo esencial la misma idea el inciso primero del art. 2329 CC, según el cual "por regla general todo daño que pueda imputarse a malicia o negligencia de otra persona, debe ser reparado por esta".

Sin que pretendamos presentar una exposición sistemática de los requisitos de la responsabilidad extracontractual en el derecho chileno, lo que ciertamente excede los márgenes del presente trabajo, cabe tener presente desde ya que, para que nazca la obligación de indemnizar perjuicios, deben concurrir los siguientes requisitos copulativos, a saber: (i) una acción u omisión, siendo especialmente relevante esta segunda hipótesis en supuestos en los que una persona se encuentra en la necesidad de observar determinados deberes de conducta impuestos por una norma25; (ii) antijuridicidad de esta acción u omisión, la cual puede llegar a ser presumida en eventos de culpa

\footnotetext{
25 La configuración de supuestos de responsabilidad por omisión es, en principio, más fácil en materia civil que en materia penal, ya que la dogmática civil entiende que basta con que el agente haya tenido cierto deber de conducta general o especial emanado del ordenamiento jurídico que le impone una posición de garante, aunque sea en términos más bien difusos o, al menos, no suficientemente tipificados, lo que no siempre equivaldrá a los casos de "posición de garante" en sentido estricto de que trata la dogmática penal, como ocurre, por ejemplo, en la hipótesis contenida en el art. 494 Nº 14 del Código Penal. Cfr. CorRal 2013, 114-115.
} 
infraccional26; (iii) nocividad, vale decir, provocación de un daño cierto, real y efectivo (no puramente incierto, hipotético o eventual); (iv) causalidad, lo cual exige complementar el análisis de la causalidad natural (elemento meramente fáctico) con criterios normativos que permitan sostener que un determinado hecho o daño debe imputarse como efecto de una conducta ${ }^{27}$; y (v) culpabilidad, esto es, un juicio de reproche personal al autor, el cual puede fundarse en una conducta dolosa (con intención positiva de dañar) o culposa (negligente), donde el estándar de cuidado exigido es el ordinario, que se contrapone a la culpa leve, que es la culpa sin otra calificación del art. $44 \mathrm{CC}^{28}$.

De la exigencia de estos cinco elementos copulativos como base de la constitución de una obligación de indemnizar perjuicios en sede extracontractual de acuerdo al derecho común en la materia, se desprende como corolario que solo en ámbitos especialmente diferenciados por el legislador, la culpabilidad no forma parte de la estructura del régimen de responsabilidad. Se trata de la así llamada responsabilidad civil estricta u objetiva, la cual por regla general encuentra su fundamento en el aprovechamiento pecuniario de una actividad riesgosa o susceptible de causar daños, normalmente de gran magnitud $^{29}$. Solo en estas hipótesis, que suponen texto legal expreso, sin que puedan inferirse o desprenderse de una interpretación extensiva o aplicación analógica de regímenes especiales ${ }^{30}$, como tampoco de una aplicación demasiado laxa o derechamente torcida de situaciones en las cuales se admite la presunción de culpa, como ocurre en el marco de la culpa infraccional, puede afirmarse que el estándar de cuidado empleado por el agente es irrelevante, y que la conexión causal entre una acción u omisión antijurídica y el daño basta por sí sola para configurar la obligación indemnizatoria.

En el evento de considerarse que el operador eléctrico ha incumplido sus deberes de mantención de las instalaciones establecidos en el art. 139 LGSE y demás disposiciones reglamentarias que lo complementan, nos enfrentaríamos, precisamente, a una hipótesis de culpa infraccional, vale decir, la contravención de ciertos deberes de cuidado "tipificados" ${ }^{11}$. La inobservancia de estos deberes permite construir un supuesto de culpa presumida por omisión, ya que del mismo modo como cuando el daño es provocado

\footnotetext{
26 Como señala CoRRal 2013, 114-115, cuando la infracción a un deber de conducta "tipificado" (así llamada infracción contravencional) provoca un daño, "el tipo infraccional funcionará a la vez como tipo de la responsabilidad sancionatoria y de la responsabilidad civil. Es decir, la tipificación prevista para contravencionales servirá también como factor indiciario de la antijuridicidad de la responsabilidad civil anexa a la infraccional".

27 Cfr. Corral 2013, 186.

${ }^{28}$ Así se desprende del inciso tercero del art. 44 CC: "(...) Culpa o descuido, sin otra calificación, significa culpa o descuido leve (...)". Al respecto, véase por todos Barros 2020, T I 86.

29 Exposiciones de conjunto en Barros 2020, T I 469 y ss.; Corral 2013, 214 y ss.

30 Hay texto expreso en este sentido, por ejemplo, en materia responsabilidad del explotador de aeronaves por daños ocasionados con ocasión de un accidente aéreo (Ley N 18.916, Código Aeronáutico), o daños provenientes del uso de instalaciones nucleares (Ley $N^{\circ} 18.302$, sobre seguridad nuclear). Cfr. DiAZ 2007, 79 y ss.

31 Cfr. Barros 2020, TI 104.
} 
por una conducta positiva, la infracción de un deber de actuar impuesto por una norma jurídica es suficiente para presumir la culpa en cuanto criterio de imputación subjetiva de responsabilidad.

En efecto, cuando un daño se produce como consecuencia de la infracción de alguna norma legal o administrativa, se considera en doctrina que el acto en principio sería ilícito y, por tanto, eventualmente desencadenante de responsabilidad extracontractual (en la medida que sea causa directa de un daño indemnizable), sin que sea necesario entrar en otras calificaciones; la declaración de ilegalidad de la conducta lleva implícita una declaración de culpabilidad, porque como expresa un autor, lo ilegal siempre lleva el sello de la culpa ${ }^{32}$. Lo dicho significa que la apreciación de la conducta del autor del daño es innecesaria, si este último tiene por causa la violación de una obligación determinada contenida en una ley o reglamento ${ }^{33}$. Luego, hay lugar a la culpa por el solo hecho de que el agente haya ejecutado el acto prohibido o no haya realizado el ordenado por la ley o el reglamento, pues significa que omitió las medidas de prudencia o precaución que se estimaron necesarias para evitar un daño.

Como ya se vio, la seguridad de las instalaciones eléctricas se encuentra sujeta a una muy detallada regulación de base técnica, por lo que se puede asumir que la observancia de las normas legales y reglamentarias es, por lo menos, un indicio de diligencia ${ }^{34}$. En cambio, el incumplimiento o cumplimiento imperfecto de alguna de estas normas trae consigo en la práctica una inversión de la carga probatoria, en el sentido de que se trataría de un indicio de negligencia. Del mismo modo como ocurre cuando el daño es producido por una acción positiva del autor, la infracción de un deber de actuar impuesto en la normativa sectorial sería suficiente para presumir la concurrencia de culpa ${ }^{35}$. Tal presunción busca favorecer a la víctima, y obedece a que el incumplimiento de deberes de cuidado constituye un hecho normativo que, por regla general, es desconocido en sus detalles por esta, pero que puede inferirse a partir de un hecho externo, como es el acaecimiento de un accidente.

Se trata, por tanto, no de una mera infracción al deber general de cuidado (alterum non laedere) consagrado en los arts. 2314 y 2329 CC, sino que a un deber jurídico especial, establecido expresamente en una norma positiva, esto es, a un deber de conducta "tipificado" (así llamada infracción contravencional), y que opera como factor indiciario de la antijuridicidad de la responsabilidad civil anexa a la infraccional ${ }^{36}$. Por cierto, lo dicho no significa que esta suerte de tipificación del ilícito civil haga innecesario acreditar los demás requisitos generales para que nazca definitivamente la obligación de

\footnotetext{
32 BARROS 2020, T I 105.

33 Alessandri 1983, 175. En el mismo sentido Corral 2013, 211.

34 Cfr. Barros 2020, TI 104.

35 Cfr. Alessandri 1983, 201.

36 Cfr. Corral 2013, 114.
} 
indemnizar; de lo contrario, la presunción de culpa derivada de la infracción de un deber normativo devendría en los hechos en una especie de responsabilidad objetiva hipertrofiada en su extensión ${ }^{37}$.

Así las cosas, para que surja responsabilidad civil, de acuerdo a las reglas de derecho común, que no han sido alteradas por la legislación especial del sector eléctrico, en supuestos de culpa infraccional siempre será necesario acreditar la imputación objetiva, esto es, el nexo causal entre el hecho ilícito y el daño, el que no se desprende de suyo del mero hecho de la infracción de una norma legal o reglamentaria. Lo anterior es de la lógica más elemental, ya que mal podría imponerse a un sujeto la obligación de indemnizar perjuicios que no son consecuencia inmediata y directa de una acción u omisión antijurídica propia. De hecho, la exigencia de una relación de causalidad se encuentra consagrada con meridiana claridad en los arts. 2314 y 2329 CC; en el primero, al disponer que quien "ha cometido un delito o cuasidelito que ha inferido daño a otro, es obligado a la indemnización"; y en el segundo, al establecer que "todo daño que pueda imputarse a malicia o negligencia de otra persona, debe ser reparado por esta"38.

Asimismo, la necesidad de acreditar la relación causal entre la infracción normativa y el daño producido se encuentra explicitada en términos claros y precisos, por ejemplo, en la legislación de tránsito ${ }^{39}$, sobre procedimiento a seguir ante los juzgados de policía local ${ }^{40}$, y en materia de responsabilidad civil por daños al medio ambiente ${ }^{41}$. Si bien se trata de ámbitos normativos distintos del objeto del presente artículo, no vemos en la especie obstáculo hermenéutico para estimar que los preceptos citados, coincidentes en lo fundamental con los arts. 2314 y 2329 CC, expresan un principio general en materia de imputación de los daños producidos por la infracción de deberes de cuidado consagrados en una ley o reglamento, atendiendo al fin de aquella o este.

En definitiva, la presunción de culpabilidad a que da lugar el incumplimiento de los deberes establecidos en el art. 139 LGSE y demás disposiciones reglamentarias que lo complementan, no constituye de suyo una

\footnotetext{
37 Ibíd., 115.

38 Cfr. Domínguez 2001, 7 y ss. Una exposición más desarrollada de la cuestión, desde una perspectiva jurisprudencial, en BARAONA 2008, 59 y ss.

39 Art. 171 de la Ley N¹8.290, de 1984: "El mero hecho de la infracción no determina necesariamente la responsabilidad civil del infractor, si no existe relación de causa a efecto entre la infracción y el daño producido por el accidente. En consecuencia, si una persona infringe alguna disposición y tal contravención no ha sido causa determinante de los daños producidos, no estará obligado a la indemnización".

40 Art. 14 Ley N 18.287, de 1984: "El solo hecho de la contravención o infracción no determina necesariamente la responsabilidad civil del infractor, si no existe relación de causa a efecto entre la contravención o infracción y el daño producido".

41 El art. 52, inciso segundo, de la Ley N 19.300, de 1994, sobre Bases Generales del Medio Ambiente, dispone que, sin perjuicio de que se presume legalmente (esto es, se admite prueba en contrario) la responsabilidad del autor del daño ambiental si existe infracción a las normas de calidad ambiental ("culpa infraccional"), "solo habrá lugar a la indemnización, en este evento, si se acreditare relación de causa a efecto entre la infracción y el daño producido".
} 
presunción de responsabilidad civil y consiguiente obligación de indemnizar perjuicios, sino que significa más bien que el operador infractor se encuentra en la necesidad de acreditar que empleó la debida diligencia (inversión de la carga probatoria), vale decir, que cumplió los deberes impuestos por una norma jurídica concreta, que no es lo mismo exactamente ${ }^{42}$. La relación causal entre la infracción legal o reglamentaria y los daños siempre deberá probarse. De ahí que bien pueda sostenerse que las presunciones de descuido de las leyes o reglamentos solo han de servir de guía al juez, ya que la vulneración de preceptos legales o reglamentarios es solo un indicio de prueba de una lesión del cuidado en el sentido de los delitos culposos, pero no una prueba del nexo causal con los daños y perjuicios verificados ${ }^{43}$.

No obstante lo anterior, un atento análisis de la jurisprudencia más reciente permite advertir en ella cierta tendencia a enmarcar la responsabilidad civil de los operadores eléctricos en un régimen que, en la práctica, es muy similar a la así llamada responsabilidad objetiva o estricta, esto es, una hipótesis de obligación de indemnizar perjuicios sin que sea necesario que concurra en absoluto un criterio de imputación subjetiva (dolo o culpa, sea esta presumida o no), en el entendido que bastaría la existencia del vínculo causal entre una acción u omisión antijurídica y el daño para que surja responsabilidad. En efecto, si bien en abstracto nadie discute que la responsabilidad objetiva o estricta requiere texto legal expreso, en la medida que constituye una excepción a la regla general de responsabilidad por culpa (arts. 2314 ss. $\mathrm{CC}$ ), los daños a las personas o a las cosas producidos dentro de la esfera de control de un operador eléctrico muchas veces son vistos por nuestros tribunales superiores como una prueba tanto de su culpa infraccional como del correspondiente nexo causal entre la infracción normativa y los perjuicios acaecidos $^{44}$. De esta guisa, la prueba de la diligencia se torna especialmente difícil (si no imposible), ya que si se produjo un daño, desde la perspectiva del tribunal ello sería porque el operador incumplió o cumplió imperfectamente alguno de sus deberes de cuidado establecidos en la normativa legal o reglamentaria aplicable.

Lo expuesto precedentemente representa una aplicación (consciente o inconsciente) por parte de los tribunales del aforismo res ipsa loquitur ("los hechos hablan por sí mismos"), en virtud del cual se asume que si se ha verificado un daño real y cierto dentro del ámbito de control del operador eléctrico, es porque este algo no hizo bien, ya que se parte de la premisa (no probada en absoluto) de que si hubiera cumplido a cabalidad todos sus deberes de cuidado, el daño no se habría producido. Así las cosas, si bien

\footnotetext{
42 Sobre esta distinción véase BAssı 2015, 85 y ss.

43 Cfr. BAssI 2017, 57.

44 Como señala Barros 2020, T l 160-161, la presunción de culpa opera cuando la cosa o la actividad que origina el daño ha estado "bajo el control del demandado, pues no puede presumirse la culpa si el daño ocurre fuera de su ámbito de control", y en la medida en que "el accidente sea de aquellos que en el curso ordinario de los acontecimientos no ocurren en ausencia de negligencia".
} 
formalmente se sigue razonando sobre la base de criterios subjetivos de imputación de responsabilidad, cuya presencia se presume, y, por tanto, dentro de los márgenes legales del estatuto de responsabilidad extracontractual regulado en los arts. 2314 ss. CC, no es menos cierto que, en la práctica, se incurre en una aplicación velada y contra texto expreso de un estatuto de responsabilidad objetiva, en cuanto bastaría la prueba de los perjuicios para vincularlos causalmente con la infracción normativa.

Esto es lo que parece estar en el razonamiento que subyace a una sentencia dictada por la Corte Suprema en 2014, donde a pesar de referirse explícitamente a la aplicación de un régimen de responsabilidad fundado en la culpa (Título XXXIII del Código Civil), e implícitamente a una infracción normativa por parte del dueño del predio sirviente, que realizó plantaciones dentro de la franja de seguridad de la servidumbre en contravención del art. 57 LGSE, acaba por imputar toda la responsabilidad al operador eléctrico, asumiendo que los daños y perjuicios derivan causalmente de su infracción "inexcusable" al art. 139 LGSE, al no tomar todas las medidas necesarias para evitarlos, sin entrar a considerar si esta última se debió a la contravención de aquél:

Que la capacidad de la demandada para cometer un ilícito civil no ha sido discutida, y aparece con toda claridad de su calidad de persona jurídica que puede ejercer derechos y contraer obligaciones civiles, según se desprende del Título XXXIII del Código Civil. En este caso Copelec Limitada responde por hecho propio, en atención a que la obligación de cuidado impuesta por el legislador radica en ella. En efecto, es la concesionaria del servicio público la que debe mantener sus instalaciones en condiciones de evitar peligros, lo que evidentemente incluye el cumplimiento de la obligación reglamentaria de mantener la faja de seguridad en buen estado (artículo 139 de la Ley General de Servicios Eléctricos y sus respectivos reglamentos). La empresa demandada no tomó las medidas necesarias para dar cumplimiento a las obligaciones legales antes referidas, y no evitó el riesgo evidente y previsible de incendio ante la interacción del bosque con líneas de transmisión de electricidad de alta tensión (...). Que en lo que respecta a culpa ya se señaló que la demandada no cumplió el deber de cuidado que le imponía la ley, consistente, en lo fundamental, en la mantención de la faja de seguridad en términos tales de evitar riesgos; deber de conducta que tiene su justificación en la necesidad de evitar accidentes e incendios que naturalmente emanan en la interacción de bosques y líneas de tendido eléctrico. Esta infracción al deber de cuidado equivale a la culpa exigida por el artículo 2314 del Código Civil, porque da cuenta de un descuido, que se hace inexcusable, ante el evidente riesgo que implica su desacato ${ }^{45}$.

En una línea argumentativa similar, se ha resuelto más recientemente que:

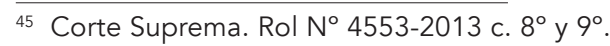


de este panorama normativo básico se desprende razonablemente que las empresas concesionarias no solo están facultadas, sino que se encuentran principalmente obligadas, a ejecutar todas las labores que resulten necesarias para la mantención de las servidumbres eléctricas de que son titulares, y si bien la ley habla de 'reparación', lo cierto es que esta actividad debe entenderse incluyendo, como es lógico, la conservación de las instalaciones, única forma en que estas funcionen en situación de garantizar el servicio de utilidad pública que importa el transporte y suministro de electricidad ${ }^{46}$.

Así las cosas, pareciera que no importara que el dueño del predio sirviente haya incumplido el deber de abstención del art. 57 LGSE o que, incluso, se haya negado injustificadamente a que trabajadores del operador eléctrico ingresen a realizar obras de mantención (lo que, por su parte, contraviene el art. 56 LGSE); si como consecuencia de lo anterior no solo se afecta la seguridad del suministro eléctrico, sino que se provocan daños en las personas o en las cosas, ello sería en sí mismo una prueba (res ipsa loquitur) de que el operador no cumplió a cabalidad los deberes de mantención ni ejerció las facultades de vigilancia contenidos principalmente en el art. 139 LGSE, arts. 205 RLGSE, 206 y 218 RLGSE, y, por ello, es civilmente responsable por el hecho propio.

Lo dicho pareciera implicar la atribución al operador eléctrico de una suerte de deber de supervigilancia respecto del cumplimiento por parte del propietario del predio sirviente de sus propios deberes, una atribución general para corregir sus deficiencias, al punto que, de no hacerlo, se podría incurrir en una "infracción gravísima" a la normativa ${ }^{47}$. Por lo demás, de la parte final del art. 57 LGSE pareciera desprenderse que la responsabilidad del dueño del suelo que infringe el deber de abstención consagrado en este precepto, quedaría limitada al reembolso del costo de las reparaciones o poda que ha tenido que efectuar directamente el operador ante la negativa injustificada de aquél, en una adaptación de las reglas de derecho común contenidas en los arts. $1553 \mathrm{~N}^{\circ} 2$ y 1555 inciso segundo $\mathrm{CC}^{48}$, sin alusión alguna a

${ }^{46}$ Corte de Apelaciones de Concepción. Rol N 15276-2018, c. 5.

47 Sin hacer alusión a eventuales incumplimientos del dueño del predio sirviente, el art. 327 RLGSE dispone que, específicamente en el caso de concesionarios del servicio público de distribución de energía eléctrica, toda infracción a los estándares de calidad del servicio indicados en el art. 222 del mismo cuerpo normativo (lo que incluye el parámetro de la seguridad de las instalaciones y el mantenimiento de las mismas, así como la oportuna atención y corrección de situaciones de emergencia y accidentes), será sancionada por la SEC como deficiente calidad de servicio, lo cual implica una hipótesis de responsabilidad administrativa, calificada bajo ciertas circunstancias en el art. 15 № 4 LSEC como una "infracción gravísima".

$48 \mathrm{El}$ art. $1553 \mathrm{CC}$ establece en su N³ que ante el incumplimiento de una obligación de hacer, el acreedor podrá pedir "que se le autorice a él mismo para hacerlo ejecutar por un tercero a costa del deudor". Por su parte, el art. 1555 CC dispone en su inciso segundo, a propósito del incumplimiento de obligaciones de no hacer, que "pudiendo destruirse la cosa hecha, y siendo su destrucción necesaria para el objeto que se tuvo en mira al tiempo de celebrar el contrato, será el deudor obligado a ella, o autorizado el acreedor para que la lleve a efecto a expensas del deudor". 
los daños que puedan provocarse a terceras personas o cosas ajenas. Ello, en cuanto los operadores no están dotados de facultades coercitivas para adoptar medidas destinadas a que el dueño del suelo ejecute por sí mismo los trabajos de reparación o poda, según corresponda.

A mayor abundamiento, esta es la interpretación que parece dar a la normativa sectorial la sentencia definitiva de primera instancia de un juicio actualmente en curso, en la que se condenó a la empresa distribuidora de energía eléctrica CGE a pagar una indemnización de perjuicios de más de mil seiscientos millones de pesos, al atribuirle responsabilidad civil por un incendio acaecido en el año 2016 en la Sexta Región. Entre los fundamentos de la sentencia, el tribunal sostuvo la existencia de:

un deber general de dar seguridad por parte de los concesionarios eléctricos, destinados mantener en buen estado sus instalaciones, evitando peligro tanto a personas o cosas, colocándolo en un lugar de garante frente a la comunidad en general, y por lo tanto, haciendo extensiva la obligación de las concesionarias de resguardo de sus líneas de tensión eléctrica independiente del lugar en que se encuentren con el objeto de prevenir siniestros, incendios u otros sucesos que importen daño a personas o cosas. De aquí entonces es que poseen una obligación de resultado y no de medios, y como consecuencia, al no haber retirado en forma previa a la ocurrencia del incendio el material combustible que estaba bajo la línea de transmisión eléctrica situado alrededor del poste es que debe responder frente a dicho incumplimiento legal y reglamentario ${ }^{49}$.

Podemos entender que, en el plano de los argumentos metajurídicos, la eventual asimetría económica y de información entre la posición del operador de instalaciones eléctricas y la víctima del daño, como asimismo, la dificultad práctica para hacer efectiva la responsabilidad del propietario superficial, cuando no se puede identificar exactamente en qué predio puede haberse iniciado un incendio, amén de la eventual limitación económica de este para indemnizar los daños causados, favorezca en los hechos el establecimiento de una línea interpretativa como la señalada, que tiende a buscar en el operador eléctrico el patrimonio que soporte el peso de la reparación, por ser quien reporta el mayor beneficio del ejercicio de una actividad económica riesgosa y quien se encuentra en una mejor posición para conocer en detalle el riesgo potencial y tomar medidas adecuadas para evitarlo, asumiendo los correspondientes gastos de prevención.

Sin embargo, no hay que olvidar que una postura interpretativa como la enunciada no cuenta con el debido sustento en la normativa sectorial sobre servicios eléctricos, que en materia de responsabilidad civil extracontractual se rigen por el derecho común: responsabilidad por culpa según lo dispuesto en los arts. 2314 ss. CC, sea esta presumida o no. A menos que la ley disponga expresamente lo contrario, no es lícito imponer un operador eléctrico la

$491^{\circ}$ Juzgado de Letras de Santa Cruz. Rol N C-1349-2017 c. $26^{\circ}$. 
obligación de indemnizar perjuicios que deriven de una acción u omisión que no le es imputable subjetivamente, es decir, que no presenta un reproche de culpabilidad en su contra; y como hemos visto, ninguna de las normas que configura el marco regulatorio de los servicios eléctricos en Chile consagra un régimen de responsabilidad estricta u objetiva (sin culpa) de los operadores: no lo hace la LGSE, ni mucho menos lo pueden hacer las disposiciones reglamentarias que la complementan, atendida su jerarquía infralegal ${ }^{50}$. Mucho menos cabe dar por acreditado el nexo causal entre una infracción normativa (que conlleva una presunción de culpa que, en todo caso, admite prueba en contrario, por difícil que esta sea) y los daños por el simple hecho de la antijuridicidad de la conducta del operador, como si la presunción de la culpa fuera equivalente a la presunción de los demás requisitos de la responsabilidad civil.

La circunstancia fáctica de que un operador eléctrico desarrolle una actividad económica que conlleva ciertos riesgos y tiene la potencialidad de causar daños a terceras personas, cosas ajenas o el medio ambiente, así como la eventual asimetría económica y de información que pudiera presentarse entre el operador y las potenciales víctimas, encontrándose el primero por regla general en una mejor posición para conocer en detalle el riesgo potencial y tomar las medidas adecuadas para conjurarlo, no justifica que la SEC o los tribunales de justicia puedan arrogarse la facultad de subvertir el sentido genuino de las normas que reglan el régimen de responsabilidad civil extracontractual establecido por la ley en este ámbito, el cual, insistimos, es el común, fundado en la culpa del autor y no en la teoría del riesgo creado, ajeno a nuestra legislación en esta materia. Por lo demás, lo dicho hunde sus raíces no solo en fundamentos de derecho civil, sino que también -y muy especialmente- en preceptos de rango constitucional, en concreto, en el principio de juridicidad consagrado en los arts. 6 y 7 CPR, que impide a un órgano del Estado que no corresponda al poder legislativo, crear un régimen de responsabilidad civil distinto del legal${ }^{51}$.

\footnotetext{
50 Esta idea se sintetiza en las siguientes palabras de CORRAL 2013, 218 ss.: "la regla general y el prototipo de responsabilidad en nuestro ordenamiento continúa siendo el de la responsabilidad por culpa (...) en nuestro sistema no puede haber objetivación de la responsabilidad por analogía o interpretación judicial, siendo necesaria la intervención del legislador. En los casos dudosos, habrá de seguirse el criterio de la responsabilidad subjetiva".

51 En virtud del principio de juridicidad, los órganos del Estado (entre los que se encuentran tanto los tribunales de justicia como la SEC) "deben someter su acción a la Constitución y a las normas dictadas conforme a ella" (art. $6^{\circ} \mathrm{CPR}$ ), y "ninguna magistratura, ninguna persona ni grupo de personas pueden atribuirse, ni aun a pretexto de circunstancias extraordinarias, otra autoridad o derechos que los que expresamente se les hayan conferido en virtud de la Constitución o las leyes" (art. $7^{\circ} \mathrm{CPR}$ ). De ahí que los tribunales no puedan atribuirse la facultad de dictar normas jurídicas, ya que carecen tanto de potestad legislativa como reglamentaria. Luego, los tribunales no están facultados para crear en los hechos y veladamente un régimen de responsabilidad civil que no se encuentra establecido expresamente en la ley: la función de los tribunales de justicia es resolver contiendas jurídicas mediante la interpretación y aplicación de la normativa vigente, no crear normas que no existen a través de una supuesta interpretación extensiva o analógica que, en realidad, lo que hace es vulnerar el genuino sentido de las normas que conforman el régimen común de responsabilidad civil extracontractual basado en la culpa,
} 
Finalmente, en la eventualidad que, a pesar de lo expuesto precedentemente, un juez de todos modos atribuyera únicamente al operador eléctrico la obligación de indemnizar los perjuicios derivados de un accidente provocado por infracciones normativas del dueño del predio sirviente (en especial, a los arts. 56 y 57 LGSE) o, en general, por no haber ejecutado "todas las labores que resulten necesarias" para mantener las instalaciones en condiciones seguras, en virtud de esa suerte de posición de garante que nuestros tribunales atribuyen a los operadores según la interpretación habitual del art. 139 LGSE y demás disposiciones reglamentarias que lo complementan, confundiendo la culpa infraccional presunta con la responsabilidad objetiva, correspondería en derecho una rebaja proporcional de la cuantía indemnizatoria, ya sea por la concurrencia de concausas en la producción de los perjuicios (la infracción del propietario del predio sirviente a los arts. 56 y 57 LGSE sería igualmente causa del daño), por la exposición imprudente de la víctima al daño (cuando es el mismo propietario del suelo infractor quien lo sufre), o por incumplimiento del deber de la víctima de mitigar el propio daño. Todo lo cual, por cierto, exige complementar el análisis de la causalidad natural (elemento meramente fáctico del accidente reportado en las instalaciones) con criterios normativos que permitan sostener que un determinado hecho o daño debe imputarse como efecto de una conducta del operador.

En lo que respecta a la concurrencia de eventuales concausas, hay que tener presente que no todas las acciones u omisiones que, desde un punto de vista físico, intervienen en un acontecimiento nocivo, pueden ser consideradas como causa de este en un sentido jurídico del término y, por ende, como suficientes para tener por acreditado el nexo causal entre hecho ilícito y daño para efectos de atribuir responsabilidad extracontractual a un sujeto. Asimismo, hay que considerar que bajo ciertas circunstancias es posible que en un acontecimiento dañoso intervenga una pluralidad de agentes, sin que necesariamente pueda imputarse responsabilidad a todos ellos. Bien puede ocurrir que la acción de un agente excluya la responsabilidad del otro al interrumpir el nexo causal, aunque esto no necesariamente será así en un régimen legal de responsabilidad objetiva (no aplicable al objeto de nuestro análisis), ya que la intervención de un tercero puede estar comprendida dentro de las situaciones de riesgo que se pretende cubrir con dicho estatuto excepcional ${ }^{52}$. Por cierto, si los causantes directos del daño fueran tanto el operador eléctrico como un tercero, entendidos ambos como coautores de un ilícito civil, cabría aplicar la regla de solidaridad contemplada en el art. 2317 CC.

En cuanto a la exposición imprudente de la víctima al daño, cabe señalar a este respecto que nuestro ordenamiento jurídico contempla expresamente una regla de atenuación de responsabilidad, contenida en el art.

el cual, como ya se ha dicho, es plenamente aplicable a los operadores eléctricos a falta de norma especial en la LGSE.

52 Cfr. Corral 2013, 186. 
$2330 \mathrm{CC}^{53}$. Esta norma consagra un deber general de evitar daños a nosotros mismos o, al menos, de mitigarlos en la medida de lo posible. Así, a pesar de que un sujeto incurra en una acción u omisión antijurídica que causa daño, se estima que no es equitativo atribuirle todo el peso del hecho ilícito y, por ende, hacerlo responsable por la integridad de los perjuicios ocasionados, si la víctima cooperó indirectamente en su producción al exponerse imprudentemente a ellos. Lo anterior será así especial, aunque no exclusivamente, cuando la forma de exposición de la víctima al daño consista en que esta infringió una norma de seguridad o deberes especiales de cuidado que tenían por finalidad su propio beneficio, como ocurre, precisamente, con los arts. 56 y 57 LGSE, cuya ratio consiste no solo en facilitar el ejercicio de la servidumbre por parte del operador eléctrico, sino que también posibilitar la adecuada mantención de las instalaciones en condiciones de evitar peligro para las personas y cosas, que va también en beneficio del propietario del suelo sometido al gravamen.

De ahí que estimemos que el cumplimiento efectivo, íntegro y oportuno del deber legal impuesto a los operadores eléctricos en materia de mantención y seguridad de las instalaciones, se complementa necesariamente con la observancia por parte del dueño del suelo de los deberes establecidos en los arts. 56 y 57 LGSE, al punto que aquél depende en gran medida de estos. De hecho, a este respecto la Corte Suprema se ha referido a obligaciones "correlativas" 54 , aunque sin llegar a las últimas consecuencias de este aserto, ya que, en general, insiste en leer en clave objetiva las normas que imponen deberes (y, con ello, responsabilidades) a los operadores eléctricos en materia de seguridad de las instalaciones, en el marco del ejercicio de una servidumbre eléctrica.

\section{Conclusiones y perspectivas}

A partir de lo expuesto en el presente estudio, podemos concluir que el incumplimiento total o parcial por parte de los operadores eléctricos del deber de velar por la seguridad de las instalaciones en los términos descritos, puede dar lugar a responsabilidad civil solo en el caso que terceras personas o cosas ajenas reporten un daño real, cierto y efectivo que sea consecuencia inmediata y directa de la infracción normativa. Lo anterior, de acuerdo a las reglas del derecho común, fundadas en la concurrencia de un factor de imputación subjetiva, a saber, la culpa leve, aunque esta sea presumida en el contexto de la así llamada culpa infraccional, como ocurre en la especie. Solo excepcionalmente, y bajo la condición indispensable de que una norma legal así lo establezca en términos explícitos, es admisible la aplicación del régimen de responsabilidad objetiva, que no requiere culpa del autor, que no es

\footnotetext{
53 Art. 2330 CC: "La apreciación del daño está sujeta a reducción, si el que lo ha sufrido se expuso a él imprudentemente". En detalle sobre esta cuestión SAN MARTín 2018.

54 Véase Corte Suprema. Rol N 14853-2018, c. 10, citado supra, n. 24.
} 
el caso de los servicios eléctricos, ya que la legislación sectorial no ha introducido cambios a este respecto.

A nuestro juicio, un estricto apego a la normativa eléctrica implica que la correcta ejecución de los correspondientes planes de roce y de acción por parte del operador debiera significar un agotamiento del deber de diligencia ordinario en el cumplimiento de las obligaciones contenidas en el art. 139 LGSE y demás disposiciones reglamentarias que lo complementan. Esto, de modo tal que la infracción del dueño del predio sirviente a los arts. 56 y 57 que impida o dificulte las labores de mantención de las instalaciones, debiera dar lugar a la ausencia de responsabilidad del operador por el hecho de un tercero o, al menos, a una atenuación de la misma ante una hipótesis de concurrencia de culpas o exposición imprudente de la víctima al daño, según el caso, ambos supuestos que tendrían como consecuencia una reducción del quantum indemnizatorio. Lo anterior, en virtud de la correlación o mutua complementariedad que se advierte entre los deberes que la LGSE impone tanto al titular de la servidumbre eléctrica como al propietario del predio sirviente en materia de seguridad de las instalaciones.

En definitiva, la oblicua aplicación a los operadores eléctricos de una suerte de responsabilidad civil objetiva, como ha venido ocurriendo hasta ahora, bajo el pretexto de que la generación del daño probaría por sí sola que no se ejecutaron "todas las labores que resulten necesarias" para evitarlo, contraviene la normativa sectorial vigente. En concreto, corresponde aplicar el régimen común de responsabilidad extracontractual por culpa, contenido en los arts. 2314 ss. CC, ya que la LGSE no ha innovado al respecto, con la salvedad de que ante una infracción normativa del operador eléctrico, su culpa se presume. Todo lo cual, por cierto, obliga a la doctrina a replantearse la importancia de la dogmática civil en el ámbito de los mercados regulados en general y del así llamado derecho eléctrico en especial.

\section{Bibliografía citada}

Alessandri, A. (1983). De la responsabilidad extra-contractual en el derecho civil chileno. Ediar.

Alessandri, A., Somarriva, M. y Vodanovic, A. (2016). Tratado de los derechos reales. Bienes. Ediciones Jurídicas de Santiago.

Baraona, J. (2008). La causa del daño en la jurisprudencia reciente (con especial referencia a la responsabilidad extracontractual). En Baraona, J., Carnevali, R., Corral, H. y Vargas, T. [eds.], La relación de causalidad. Análisis de su relevancia en la responsabilidad civil y penal (pp. 59-113). Universidad de los Andes.

Barros, E. (2020). Tratado de responsabilidad extracontractual ( $2^{a}$ edición) (Tomo I). Editorial Jurídica de Chile.

Bassi, F. (2015). Visión crítica de la culpa infraccional como criterio de atribución de responsabilidad extracontractual. [Memoria para optar al Grado de Licenciado en Ciencias Jurídicas y Sociales, Universidad de Chile].

Bassi, F. (2017). Culpa infraccional. Elementos para una perspectiva crítica sobre sus efectos jurídicos en el derecho civil chileno. Revista de Estudios de la Justicia (27), 37-59.

Bermúdez, J. (2012). Las relaciones entre el derecho administrativo y el derecho común. Derecho positivo, doctrina y jurisprudencia. AbeledoPerrot. 
Corral, H. (2013). Lecciones de responsabilidad civil extracontractual ( $2^{a}$ edición). LegalPublishing/Thomson Reuters.

Corral, H. (2020). Curso de derecho civil. Bienes. Thomson Reuters.

Díaz, R. (2007). Responsabilidad objetiva en el ordenamiento jurídico chileno. Revista de Derecho de la Universidad Católica del Norte (14/1), 79-112.

Díaz, I. (2018). Régimen de acceso a predios sirvientes y servidumbres de tránsito en la Ley General de Servicios Eléctricos. Revista de Derecho Administrativo Económico (26), 41-56.

Domínguez, R. (2001). Aspectos de la relación de causalidad en la responsabilidad civil con especial referencia al derecho chileno. Revista de Derecho de la Universidad de Concepción (209), 7-27.

Evans, E. (2006). Derecho eléctrico. LexisNexis.

Machuca, L. (2017). Corta de bosques bajo tendidos eléctricos. Revista de Derecho Administrativo Económico (25), 135-143.

Mejías, C. (2018). El derecho común presupuesto en el ordenamiento jurídico nacional. Una revisión de su contenido. Revista Chilena de Derecho (45/3), 621-646.

Parada, P. (2019). Regímenes de responsabilidad del Coordinador Independiente del Sistema Eléctrico Nacional. Revista de Derecho Administrativo Económico (29), 85-115.

Peñailillo, D. (2019). Los bienes. La propiedad y otros derechos reales (2 $2^{\mathrm{a}}$ edición). Thomson Reuters.

San Martín, L. (2018). La culpa de la víctima en la responsabilidad civil. Der.

Sepúlveda, E. (2010). Sistema y mercado eléctricos. LegalPublishing.

Vergara, A. (2010). El derecho administrativo como sistema autónomo. El mito del código civil como 'derecho común'. AbeledoPerrot.

Vergara, A. (2018a). Derecho Eléctrico. Editorial Jurídica de Chile.

Vergara, A. (2018b). Derecho administrativo económico. Sectores regulados: servicios públicos, territorio y recursos naturales. Thomson Reuters.

\section{Normativa citada}

Fija texto refundido, coordinado y sistematizado del Código Civil; de la Ley $N^{\circ} 4.808$, sobre registro civil, de la Ley $N^{\circ} 17.344$, que autoriza cambio de nombres y apellidos, de la Ley $N^{\circ} 16.618$, ley de menores, de la Ley $N^{\circ} 14.908$, sobre abandono de familia y pago de pensiones alimenticias, y de la Ley $\mathrm{N}^{\circ} 16.271$, de impuesto a las herencias, asignaciones y donaciones [CC]. DFL 1 de 2000. 16 de mayo de 2000 (Chile).

Constitución Política de la República [Const.]. Art. 19N 24 y 7.21 de octubre de 1980 (Chile).

Ley $N^{\circ} 18.290$ de 1984. Ley de tránsito. 23 de enero de 1984. D.O. N 31.791.

Ley $N^{\circ} 18.287$ de 1984. Establece procedimiento ante los juzgados de policía local. 2 de marzo de 1984. D.O. N³1.824.

Ley No 18.410. Crea la Superintendencia de Electricidad y Combustibles. 26 abril 1985. D.O. No 32.152.

Ley $\mathrm{N}^{\circ}$ 19.300. Aprueba ley sobre bases generales del medio ambiente. 1 de marzo de 1994. D.O. No 34.810.

Decreto $\mathrm{N}^{\circ} 4$ de 2007 [con fuerza de ley]. Fija el texto refundido, coordinado y sistematizado del Decreto con Fuerza de Ley No 2 del Ministerio de Minería, de 1982, Ley General de Servicios Eléctricos. 12 de mayo de 2006. D.O. N 38.681.

Decreto No327 de 1998 [Ministerio de Minería]. Fija reglamento de la ley general de servicios eléctricos. 12 de diciembre de 1997.

Decreto No 109 [Ministerio de Energía]. Aprueba Reglamento de Seguridad de las Instalaciones Eléctricas destinadas a la Producción, Transporte, Prestación de Servicios Complementarios, Sistemas de Almacenamiento y Distribución de Energía Eléctrica. 3 de noviembre de 2017.

Circular $N^{\circ} 26.035$ [Superintendencia de electricidad y combustibles]. Imparte nuevas instrucciones sobre mantenimiento de instalaciones, corte y poda de árboles en las proximidades de líneas eléctricas. 15 de diciembre de 2017.

Ordinario Nº 195 [Dirección Regional de la Araucanía de la SEC]. 21 de junio de 2019. 


\section{Jurisprudencia citada}

Corte de Apelaciones de Concepción. Tercera Sala. Rol No 7093-2013. 28 abril 2014. Corte Suprema. Cuarta Sala. Rol N 4553-2013. 7 mayo 2014.

Corte de Apelaciones de Concepción. Primera Sala. Rol N 6990-2017. 12 enero 2018. Corte de Apelaciones de Concepción. Primera Sala Rol Nº 6948-2017. 2 marzo 2018. Corte de Apelaciones de Concepción. Tercera Sala. Rol No 867-2018. 29 marzo 2018. Corte Suprema. Tercera Sala. Rol No 115-2018. 11 abril 2018.

Corte Suprema. Primera Sala. Rol No 34224-2017. 6 agosto 2018.

Corte Suprema. Tercera Sala. Rol No 14853-2018. 30 agosto 2018.

Corte Suprema. Tercera Sala. Rol No 14854-2018. 30 agosto 2018.

Corte Suprema. Tercera Sala. Rol No 14855-2018. 30 agosto 2018.

Corte Suprema. Tercera Sala. Rol No 14856-2018. 30 agosto 2018.

Corte Suprema. Tercera Sala. Rol No 14857-2018. 30 agosto 2018.

Corte de Apelaciones de Concepción. Segunda Sala. Rol No 15276-2018. 9 mayo 2019.

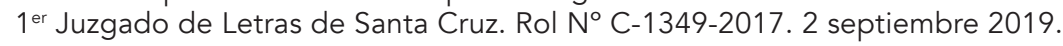

